\title{
APLIKASI SIG UNTUK ANALISIS KESESUAIAN KAWASAN BUDIDAYA TERIPANG PASIR (Holothuria scabra) DENGAN METODE PENCULTURE DI PERAIRAN TELUK KIOWA, DESA KAHYAPU KECAMATAN ENGGANO
}

\author{
Oleh \\ Ully Wulandari ${ }^{1 *}$, Bambang Sulistyo ${ }^{2}$ dan Dede Hartono ${ }^{1}$ \\ ${ }^{1}$ Program Studi IImu Kelautan Fakultas Pertanian Universitas Bengkulu, Bengkulu \\ ${ }^{2}$ Program Studi IImu Tanah Fakultas Pertanian Universitas Bengkulu, Bengkulu \\ *Email: ully.wulandari@yahoo.co.id \\ Received February 2016, Accepted March 2016
}

\begin{abstract}
ABSTRAK
Penelitian ini bertujuan untuk menganalisis kesesuaian kawasan budidaya teripang menggunakan Aplikasi SIG yang disajikan dalam bentuk Peta Kesesuaian Kawasan Budidaya Teripang Pasir (Holothuria scabra) di Perairan Teluk Kiowa, Desa Kahyapu Kecamatan Enggano Kabupaten Bengkulu Utara. Penelitian ini dilakukan dengan metode penentuan tingkat kesesuaian kawasan budidaya berdasarkan Matriks Kesesuaian Kawasan Budidaya Teripang Pasir (Holothuria scabra) dalam menghasilkan Peta Kesesuaian Kawasan Budidaya Teripang Pasir (Holothuria scabra) yang ditentukan oleh Kriteria, Bobot dan Skor tiap parameter (kedalaman, kondisi dasar perairan, kecerahan, salinitas, derajat keasaman, keterlindungan, kandungan oksigen terlarut, dan suhu permukaan laut). Penelitian ini dikhususkan untuk Kesesuaian Kawasan Budidaya Teripang Pasir (Holothuria scabra) dengan metode Penculture. Berdasarkan hasil analisis, Perairan Teluk Kiowa merupakan perairan dengan persentase kesesuaian yang bervariasi sebagai kawasan budidaya Teripang Pasir (Holothuria scabra) dengan metode Penculture. Kelas Sangat Sesuai (S1) seluas 102,477 Ha, kelas Sesuai (S2) seluas 62,435 Ha, dan kelas Tidak Sesuai (S3) seluas 197,991 Ha.
\end{abstract}

Kata kunci : Pulau enggano, sistem informasi geografis (sig), kesesuaian kawasan budidaya teripang pasir (holothuria scabra)

\section{ABSTRACT}

This study aims to analyze the suitability of sea cucumber cultivation area using GIS applications presented in the form of Suitability Map Aquaculture Zone for Sea Cucumber (Holothuria scabra) in Gulf Kiowa, Kahyapu Village District of Enggano, North Bengkulu. This study's conducted by determining suitability level method of area based on suitability matrix of Sea Cucumber (Holothuria scabra) Aquaculture Zone to contribute the region Suitability Map Aquaculture Zone for Sea Cucumber (Holothuria scabra) are determined by the criteria, Weight and score for each parameter (depth, seabed conditions, brightness, salinity, acidity, savety, dissolved oxygen, and temperature). This study is devoted to Conformity Sea Cucumber (Holothuria scabra) Aquaculture Zone with Penculture method. Based on the analysis, Kiowa Gulf have many variation percentage of suitability as Aquaculture Zone of Sea cucumbers (Holothuria scabra) with Penculture method. The Highly Suitable class (S1) covering $102.477 \mathrm{Ha}$, for Suitable class (S2) covering $62.435 \mathrm{Ha}$, and for Not Suitable class (S3) covering $197.991 \mathrm{Ha}$. 
Key words: Enggano, geographic information systems (gis), conformity aquaculture zone of sea cucumber (holothuria scabra)

\section{PENDAHULUAN}

Teripang merupakan hasil laut yang bernilai ekonomis penting, selama ini teripang diperoleh dari aktifitas penangkapan, sehingga ketersediaan teripang di alam menjadi semakin langka sehingga budidaya semakin penting dilakukan sebagai alternatifnya.

Menurut Dinas Kelautan dan Perikanan yang bekerja sama dengan CV. Mitra Konsultan (2004), perairan Pulau Enggano memiliki sumber daya alam yang cukup potensial untuk dimanfaatkan, dikembangkan dan dikelola sebagai sumber pertumbuhan ekonomi daerah. Dalam rancangan tata ruang potensi Pulau Enggano, disebutkan bahwa kawasan perairan Teluk Kiowa, Desa Kahyapu merupakan kawasan yang direkomendasikan sebagai kawasan perikanan budidaya. Untuk itu perlu dilakukan suatu pengkajian dengan maksud untuk mengetahui daya dukung lingkungan sehingga akan diketahui berapa persen tingkat kesesuaian kawasan untuk budidaya teripang (dalam hal ini teripang pasir).

\section{Waktu dan Lokasi Penelitian}

\section{METODOLOGI PENELITIAN}

Penelitian ini dilakukan di perairan Teluk Kiowa, Desa Kahyapu Kecamatan Enggano selama 6 bulan (Oktober 2014 - April 2015).

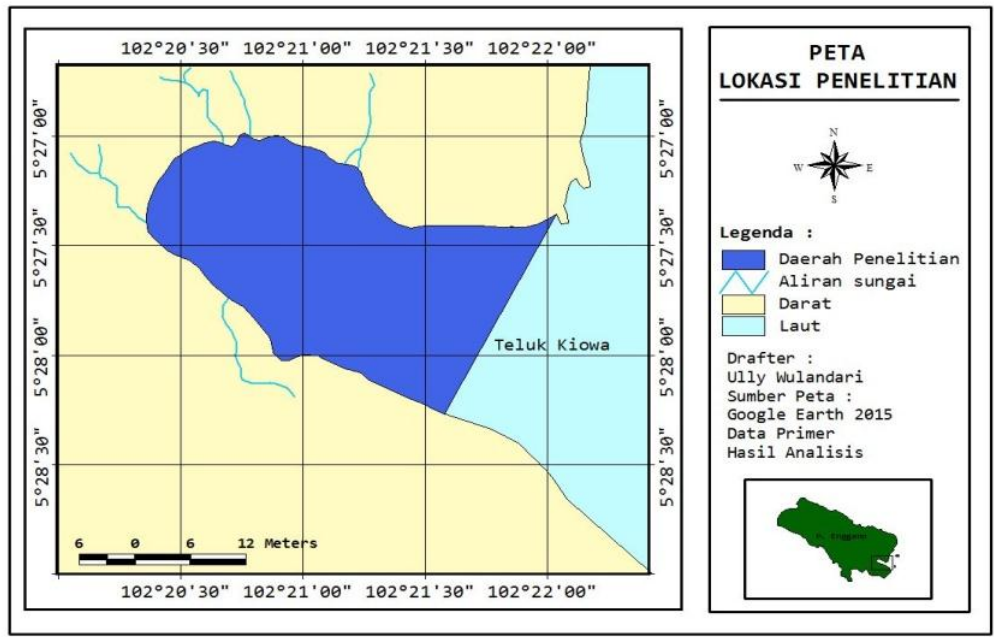

Gambar 1. Peta Lokasi Penelitian (Sumber: Google Earth, 2015)

\section{Alat dan Bahan}

Penelitian ini menggunakan dua macam alat, yaitu alat yang digunakan saat pengambilan data di lapangan (Tabel 1) dan pengolahan data di laboratorium (Tabel 2). Bahan yang digunakan dalam penelitian ini adalah data digital Pulau Enggano dari Google Earth tahun 2015 yang kemudian didigitasi dan dijadikan sebagai peta dasar untuk membuat peta tematik. 
Tabel 1. Alat yang digunakan saat pengambilan data di lapangan

\begin{tabular}{lll}
\hline No & Nama Alat & Fungsi \\
\hline 1 & Kapal & $\begin{array}{l}\text { Alat transportasi menuju teluk kiowa sekaligus tempat } \\
\text { untuk mengambil data di setiap titik sampling }\end{array}$ \\
\hline 2 & Currentmeter & Untuk mengukur suhu perairan dan kecepatan arus \\
\hline 3 & Refraktometer & Untuk mengukur salinitas \\
\hline 4 & Seichi Disc & Untuk mengukur kecerahan \\
\hline 5 & pH Meter & Untuk mengukur pH perairan \\
\hline 7 & Getra Test Kit $\mathrm{O}_{2}$ & Untuk mengukur kandungan oksigen terlarut (DO) \\
\hline 8 & Positioning System) & Untuk mengambil koordinat setiap titik sampling \\
\hline 9 & Kamera & Untuk mengambil substrat dasar perairan \\
\hline 10 & Tali & Untuk mengambil gambar atau foto saat melakukan \\
\hline 11 & Papan Pasut & sampling \\
\hline
\end{tabular}

Tabel 2. Alat yang digunakan saat pengolahan data di laboratorium

\begin{tabular}{lll}
\hline No & Nama alat & Fungsi \\
\hline 1 & Notebook ASUS & Menginput dan mengolah data \\
\hline 2 & Scanner / Printer & Untuk mencetak hardcopy yang dihasilkan \\
\hline 3 & Compact disk & Untuk menyimpan data yang akan dikumpulkan \\
\hline 4 & Ms. Word 2007 & Untuk membuat pembahasan dari penelitian \\
\hline 5 & Ms. Excel 2007 & $\begin{array}{l}\text { Untuk mengolah data dari setiap parameter yang akan di } \\
\text { input ke dalam aplikasi surfer }\end{array}$ \\
\hline 6 & Surfer 12 & $\begin{array}{l}\text { Mengolah data dari Ms. Excel, membuat peta kontur atau } \\
\text { batimetri }\end{array}$ \\
\hline 7 & ArcView 3.3 & $\begin{array}{l}\text { Untuk membuat peta lahan kesesuaian kawasan budidaya } \\
\text { teripang }\end{array}$ \\
\hline
\end{tabular}

\section{Prosedur Penelitian}

\section{Penentuan Lokasi Penelitian}

1. Keterlindungan Pantai, lokasi budidaya harus terlindung dari pengaruh arus, gelombang maupun angin yang besar karena akan merusak sarana budidaya serta menyulitkan dalam pengelolaan budidaya

2. Kondisi dasar Perairan, hendaknya berpasir, atau pasir berlumpur bercampur dengan pecahan karang dan banyak terdapat tanaman air semacam lamun karena banyak mengandung detritus

3. Parameter Fisika dan Kimia, salinitas yang sangat sesuai berkisar 32\%$35 \%$, kedalaman yang sangat sesuai berkisar $1-1,5$ meter, untuk $\mathrm{pH}$ yang sangat sesuai berkisar 7,5-8,5, kecerahannya berkisar 100-150 cm, kandungan oksigen terlarut yang sangat sesuai berkisar $6-8 \mathrm{ppm}$, suhu yang sangat sesuai berkisar $26-31^{\circ} \mathrm{C}$ 
4. Faktor Pembatas, seperti bangunan rumah atau kelong, pelabuhan, dll

\section{Penentuan Titik Sampling}

Dilakukan secara acak pada setiap titik pemberhentian kapal, agar lokasi yang terpilih dapat mewakili dari daerah yang akan diteliti dengan asumsi bahwa semakin banyak titik yang diambil maka semakin bagus hasil interpolasinya. Pada lokasi penelitian ini titik pengambilan sampel diambil sebanyak 51 titik pada 51 kali pemberhentian kapal.

\section{Pengambilan Sampel}

Dilakukan mulai pukul 10.00-17.00 WIB dengan tiga kali pengulangan. Pengukuran atau sampling yang dilakukan dilapangan (in-situ) adalah pengukuran terhadap parameter kimia dan fisika perairan.

\section{Analisis Spasial \\ Matrik pembobotan dan skoring}

Metode ini umumnya selalu berhadapan dengan variable yang bersifat kualitatif. Setiap variabel kesesuaian diberi bobot yang besarnya ditentukan oleh kontribusi atau peranan yang diberikan oleh parameter tersebut, dikarenakan setiap parameter memiliki andil yang berbeda dalam menunjang kehidupan komoditas. Tabel kriteria, bobot dan skor dapat dilihat pada Tabel 3.

Tabel 3. Kriteria, Bobot, dan Skor

\begin{tabular}{|c|c|c|c|}
\hline No & Kriteria & Bobot & Skor \\
\hline 1 & Kondisi Dasar Perairan & 20 & \\
\hline & S1 (Pasir berlumpur dan Patahan Karang) & & 3 \\
\hline & S2 (Pasir dan Lumpur) & & 2 \\
\hline & S3 (Pasir atau Lumpur) & & 1 \\
\hline 2 & Keterlindungan & 10 & \\
\hline & S1 (Terlindung) & & 3 \\
\hline & S2 (Kurang Terlindung) & & 2 \\
\hline & S3 (Terbuka) & & 1 \\
\hline 3 & Kedalaman & 20 & \\
\hline & $\mathrm{S} 1(1-1,5 \mathrm{~m})$ & & 3 \\
\hline & $\mathrm{S} 2(0,5 \mathrm{~m}-1 \mathrm{~m})$ & & 2 \\
\hline 4 & Salinitas & 10 & \\
\hline & S1 (32\% - $35 \%)$ & & 3 \\
\hline & S2 (24\% - $32 \%)$ & & 2 \\
\hline & $(24 \%<$ S3 > $35 \%)$ & & 1 \\
\hline 5 & Derajat Keasaman & 10 & \\
\hline & S1 $(7,5-8,5)$ & & 3 \\
\hline & $S 2(6,5-7,5)$ & & 2 \\
\hline & S3 $(5,5-6,5)$ & & 1 \\
\hline 6 & Kecerahan & 10 & \\
\hline & $\mathrm{S} 1(100-150 \mathrm{~cm})$ & & 3 \\
\hline & $\mathrm{S} 2(50-100 \mathrm{~cm})$ & & 2 \\
\hline & $\mathrm{S} 3(<50 \mathrm{~cm})$ & & 1 \\
\hline 7 & Oksigen Terlarut & 10 & \\
\hline
\end{tabular}




\begin{tabular}{lll}
\hline & $\mathrm{S} 1(6 \mathrm{ppm}-8 \mathrm{ppm})$ & 3 \\
\hline & $\mathrm{S} 2(3 \mathrm{ppm}-6 \mathrm{ppm})$ & 2 \\
\hline & $(3 p p m<\mathrm{S} 3>8 \mathrm{ppm})$ & 1 \\
\hline $8 \quad$ Suhu Perairan & 10 \\
\hline $\mathrm{S} 1\left(26^{0} \mathrm{C}-31^{0} \mathrm{C}\right)$ & 3 \\
\hline $\mathrm{S} 2\left(20-25^{\circ} \mathrm{C}\right)$ & 2 \\
\hline & $\left(19^{0} \mathrm{C}<\mathrm{S} 3>31^{0} \mathrm{C}\right)$ & 1 \\
\hline
\end{tabular}

Sumber: Modifikasi Marizal $d k k$ (2012)

Hasil perkalian bobot dan skor tertinggi adalah 300, sedangkan nilai perkalian bobot dan skor terendah adalah 100. Untuk mengelompokkan kesesuaian perairan kedalam 3 kategori yaitu Sangat Sesuai (S1), Sesuai (S2) dan Tidak Sesuai (S3) dapat dilihat dari hasil perkalian nilai bobot dengan skor. Untuk perkalian bobot dengan skor berkisar antara >200-300 termasuk katagori Sangat Sesuai (S1), sedangkan perkalian bobot dengan skor berkisar antara >100-200 termasuk katagori Sesuai (S2).Sementara itu perkalian bobot dengan skor yang memiliki nilai 100 termasuk katagori Tidak Sesuai (S3).

\section{Analisis Overlay}

Setelah data basis dan data spasial telah terbentuk, langkah selanjutnya adalah melakukan analisis tumpang susun atau Overlay yang menggabungkan informasi beberapa peta untuk menghasilkan informasi yang baru, Overlay merupakan kemampuan analisis keruangan yang dapat dilakukan secara efektif dalam SIG. Hasil dari analisis keruangan adalah berupa peta untuk kesesuaian kawasan budidaya teripang.

\section{Kelas Kesesuaian \\ Matriks Kesesuaian}

Metode ini mengadopsi teknik analisis kesesuaian lahan yang dikembangkan oleh FAO dalam Badan Penelitian Dan Pengembangan Pengelolaan Sumberdaya Perairan Dan Lingkungan Universitas Riau (2009). Pada metode ini setiap variabel/kriteria penetapan kesesuaian ruang diberi nilai yang dibagi dalam 3 kelas, yaitu:

1) S1 : Sangat Sesuai (Higly Suitable), daerah ini tidak mempunyai pembatas yang berat untuk suatu penggunaan tertentu secara lestari, atau hanya mempunyai pembatas yang kurang berarti dan tidak berpengaruh secara nyata terhadap produksi/masukan tingkat perlakuan yang diberikan

2) S2 : Sesuai (Suitable), daerah ini mempunyai pembatas yang agak berat untuk penggunaan tertentu secara lestari. Pembatas tersebut akan meningkatkan masukan/tingkatan perlakuan yang diberikan

3) S3 : Tidak Sesuai (Not Suitable), daerah ini mempunyai pembatas dengan tingkat sangat serius, sehingga tidak mungkin untuk diperbaiki, dengan kata lain tidak mungkin untuk dipergunakan terhadap sesuatu penggunaan tertentu secara lestari.

Penentuan nilai total digunakan rumus yang mengacu pada Marizal $d k k$ (2012):

Keterangan :

$$
\mathrm{N}=\frac{\sum \text { BixSi }}{\text { Keseluruhan bobot }}
$$

$\mathbf{N}=$ Total Nilai

$\mathbf{B i}=$ Bobot Pada Tiap Kriteria 
$\mathbf{S i}=$ Skor Pada Tiap Keriteria

Penentuan nilai kelas kesesuaian kawasan budidaya teripang juga mengacu pada Marizal $d k k$ (2012), yaitu:

$$
\begin{aligned}
\mathrm{N} \min & =\frac{\sum \text { Bobot pada setiap kriteria }}{\text { Keseluruhan bobot }} \\
\mathrm{N} \max & =\frac{\sum \text { Keseluruhan Skor }}{\text { Keseluruhan Parameter }}
\end{aligned}
$$$$
\text { Selang Interval Kelas }=\frac{\sum N m a x-N m i n}{3}
$$

Dari perhitungan menggunakan rumus diatas dihasilkan selang interval kelas sebesar 0,65 dengan nilai N.min sebesar 1.00 dan N.max sebesar 2.97. Mengacu pada metode yang digunakan oleh Marizal dkk (2012), masing-masing kelas dapat ditetapkan selang dari bobot nilainya sebagai berikut:

1) Sangat sesuai: Nilai $2,32-2,97$

2) Sesuai : Nilai $1,66-2,31$

3) Tidak sesuai : Nilai $1,00-1,65$

\section{Intersect Kelas Sangat Sesuai (S1)}

Setelah didapat daerah kesesuaian kawasan budidaya teripang, khusus bagi daerah yang sangat sesuai dibuat coverage baru, tujuannya untuk mendapatkan suatu daerah yang mempunyai kesesuaian yang sangat baik, dan kemudian daerah tersebutlah yang sesuai untuk budidaya teripang di Perairan Teluk Kiowa, Desa Kahyapu Kecamatan Enggano Kabupaten Bengkulu Utara.

\section{HASIL DAN PEMBAHASAN}

\section{Peta Hasil Untuk Analisis Kesesuaian}

Setelah pembuatan peta dasar, data atribut dari masing-masing parameter dimasukkan dan diolah dengan menggunakan aplikasi Surfer 12 untuk mendapatkan peta kontur dari setiap parameter. Budiyanto (2005) dalam Munirwansyah dkk (2013), pembuatan peta kontur ataupun model tiga dimensi dalam surfer diawali pembuatan data tabular XYZ. Garis kontur itu sendiri adalah garis khayal untuk menggambarkan semua titik yang mempunyai ketinggian yang sama di atas atau di bawah permukaan datum tertentu yang disebut permukaan laut rata-rata (Hertanto, 2012). Peta kontur tiap parameter yang dihasilkan kemudian di export dalam format shp, dan kemudian ditampilkan pada aplikasi ArcView 3.3 untuk dilakukan analisis spasial dengan menginterpolasi data atribut masing-masing parameter.

\section{Peta Kedalaman}

Lokasi yang cocok untuk budidaya teripang sebaiknya pada kisaran kedalaman air antara 0,5-1,5 m pada air surut terendah (Firdausi, 2010). Penelitian ini, memanfaatkan aplikasi Surfer 12 untuk membuat peta kontur, garis kontur yang dihasilkan dapat dilihat pada Gambar 2. 


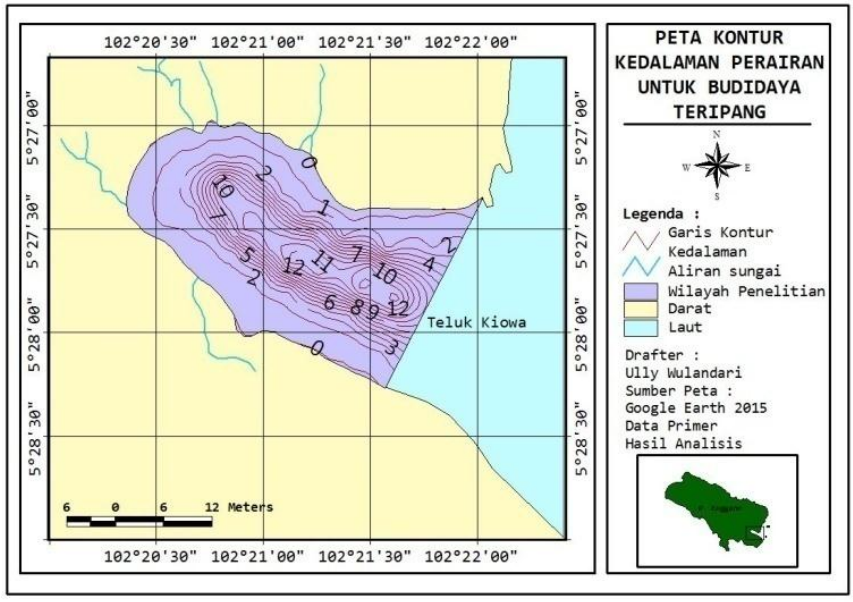

Gambar 2. Peta Kontur Kedalaman

Gambar 3, dapat di prediksi bahwa kawasan yang cocok sebagai Lahan Budidaya Teripang Pasir (Holothuria scabra) hanya pada bagian pinggir dengan luas yang tidak begitu besar bila di banding dengan bagian teluk yang dalam. Luas kesesuaian kedalaman perairan disajikan pada Tabel 4.

Tabel 4. Tabel luas kelas kesesuaian kedalaman perairan

\begin{tabular}{llll}
\hline No & Kelas Kesesuaian & Luas $(\mathrm{Ha})$ & Luas $(\%)$ \\
\hline 1 & Tidak Sesuai & 265,839 & 72,65 \\
\hline 2 & Sesuai & 49,794 & 13,6 \\
\hline 3 & Sangat Sesuai & 50,270 & 13,75 \\
\hline Total & & 365,903 & 100 \\
\hline
\end{tabular}

Pada lokasi penelitian, yaitu Perairan Teluk Kiowa kedalaman yang masuk sebagai kelas Sangat Sesuai (S1) seluas 50,270 Ha untuk kelas Sesuai (S2) adalah seluas 49,794 Ha, sedangkan untuk kelas Tidak Sesuai (S3) adalah yang paling luas, yaitu seluas $265,839 \mathrm{Ha}$. Hasil dari proses analisis spasial yang sudah dilakukan untuk parameter kedalaman dapat dilihat pada Gambar 3.

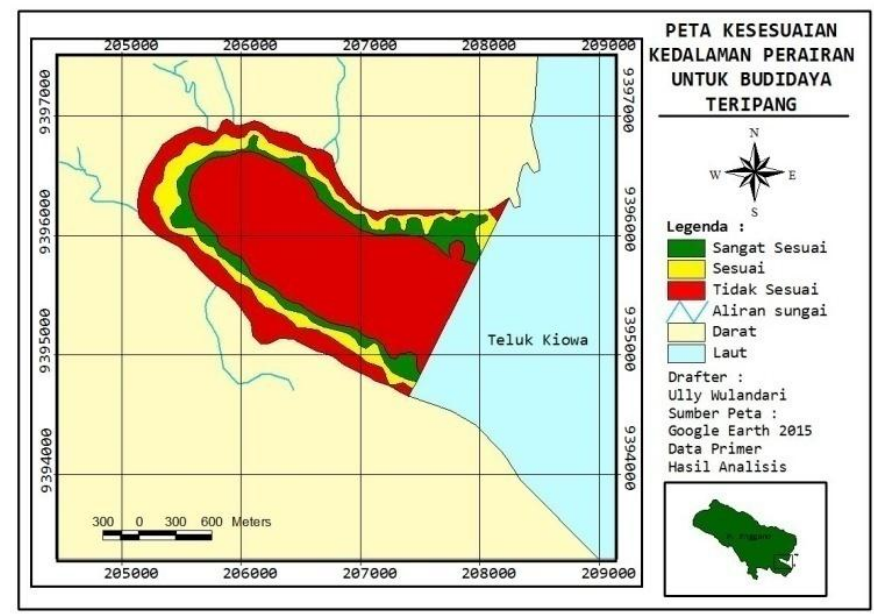

Gambar 3. Peta Kedalaman 


\section{Peta Kondisi Dasar Perairan}

Salah satu faktor yang perlu diperhatikan untuk budidaya teripang menurut Kementrian Kelautan dan Perikanan (2012) adalah dasar perairan. Garis kontur kondisi dasar perairan terlihat pada Gambar 4.

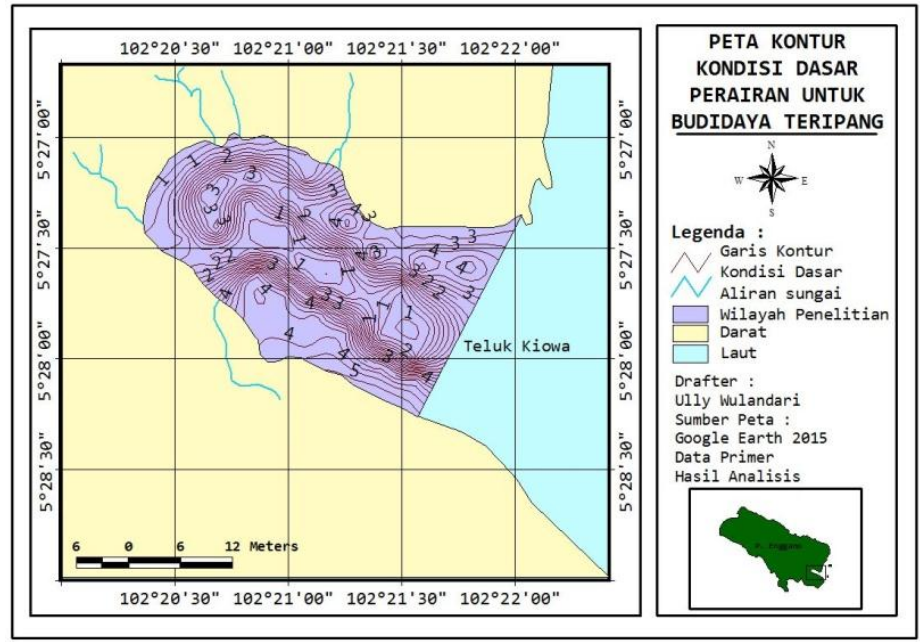

Gambar 4. Peta Kontur Kondisi Dasar Perairan

Adanya garis kontur, akan lebih mudah dalam melihat bayangan hasil analisis spasial yang akan dihasilkan, luas kesesuaian kondisi dasar perairan hasil analisis spasial disajikan pada Tabel 5.

Tabel 5. Tabel luas kelas kesesuaian kondisi dasar perairan

\begin{tabular}{llll}
\hline No & Kelas Kesesuaian & Luas $(\mathrm{Ha})$ & Luas $(\%)$ \\
\hline 1 & Tidak Sesuai & 152,976 & 41,791 \\
\hline 2 & Sesuai & 83,718 & 22,87 \\
\hline 3 & Sangat Sesuai & 129,208 & 35,339 \\
\hline Total & & 365,903 & 100 \\
\hline
\end{tabular}

Hasil pengambilan data langsung di lokasi penelitian, daerah dengan kondisi dasar pasir patahan karang adalah seluas 129,208 Ha, kondisi ini merupakan kelas Sangat Sesuai (S1). Titik sampling dengan kondisi dasar pasir berlumpur adalah seluas $83,718 \mathrm{Ha}$, kondisi ini merupakan dasar perairan dengan kelas Sesuai (S2). Pada kategori Tidak Sesuai (S3) adalah perairan dengan kondisi dasar pasir atau lumpur, untuk lokasi penelitian ini kelas S3 memiliki kawasan terluas, yaitu 152,976 Ha. Hasil dari proses analisis ini dapat dilihat pada Gambar 5 . 


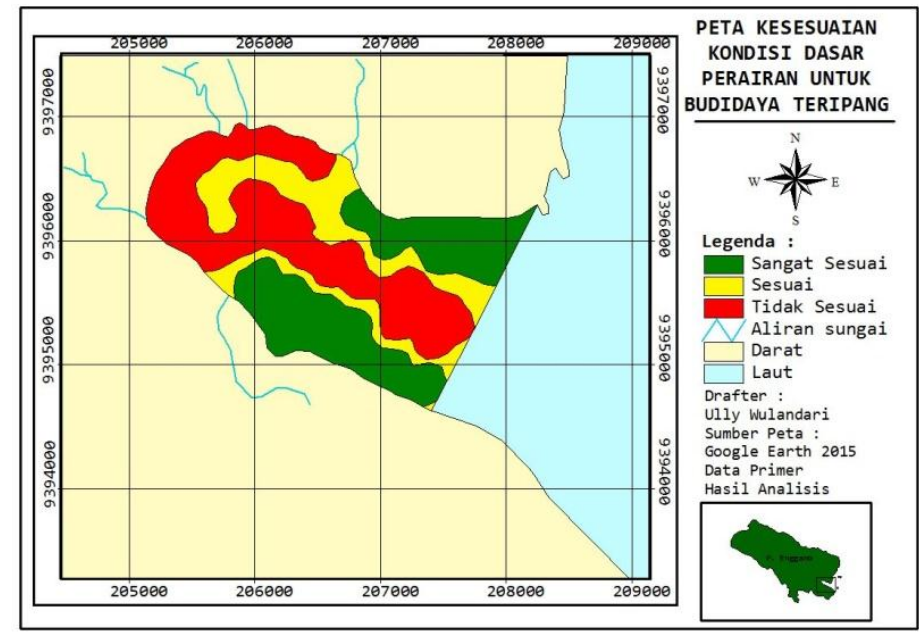

Gambar 5. Peta Kondisi Dasar Perairan

\section{Peta Kecerahan}

Kecerahan pada Teluk Kiowa berkisar hanya antara Sesuai dan Sangat Sesuai, hal ini dikarenakan Perairan Teluk Kiowa memiliki kecerahan tidak kurang dari $50 \mathrm{~cm}$ dan tidak lebih dari $150 \mathrm{~cm}$. Garis kontur yang dihasilkan dalam analisis dapat dilihat pada Gambar 6. Hasil analisis spasial memberikan informasi mengenai luas kawasan kesesuaian kecerahan perairan, seperti yang disajikan pada Tabel 6 .

Tabel 6. Tabel luas kelas kesesuaian kecerahan perairan

\begin{tabular}{llll}
\hline No & Kelas Kesesuaian & Luas $(\mathrm{Ha})$ & Luas $(\%)$ \\
\hline 1 & Tidak Sesuai & 0 & 0 \\
\hline 2 & Sesuai & 48,545 & 13,27 \\
\hline 3 & Sangat Sesuai & 317,358 & 86,73 \\
\hline Total & & 365,903 & 100 \\
\hline
\end{tabular}

Hasil interpolasi dan analisis spasial menunjukan bahwa kategori Sangat Sesuai (S1) adalah yang mendominasi Perairan Teluk Kiowa, seperti yang terlihat pada Gambar 7.

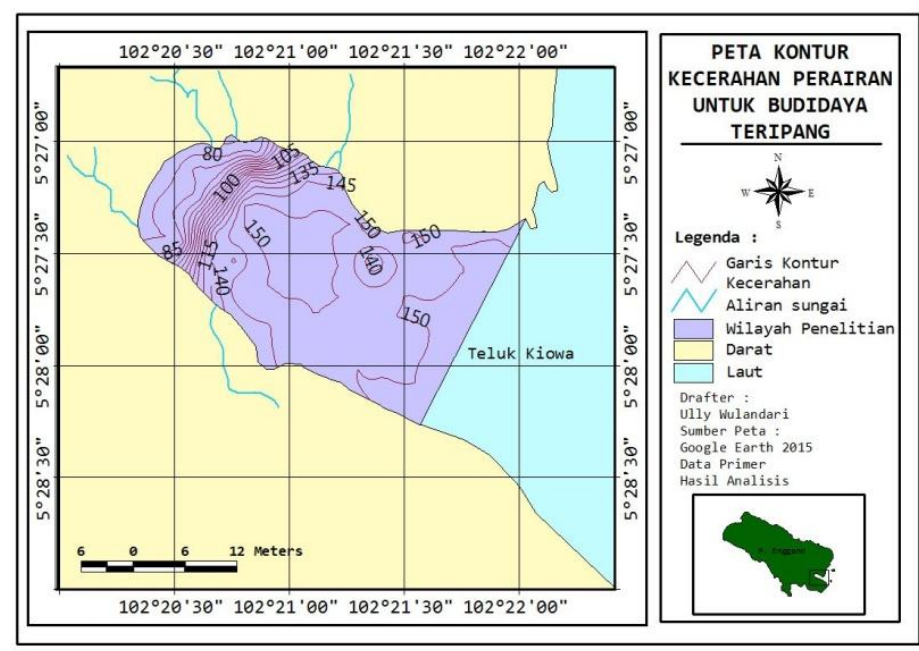

Gambar 6. Peta Kontur Kecerahan 


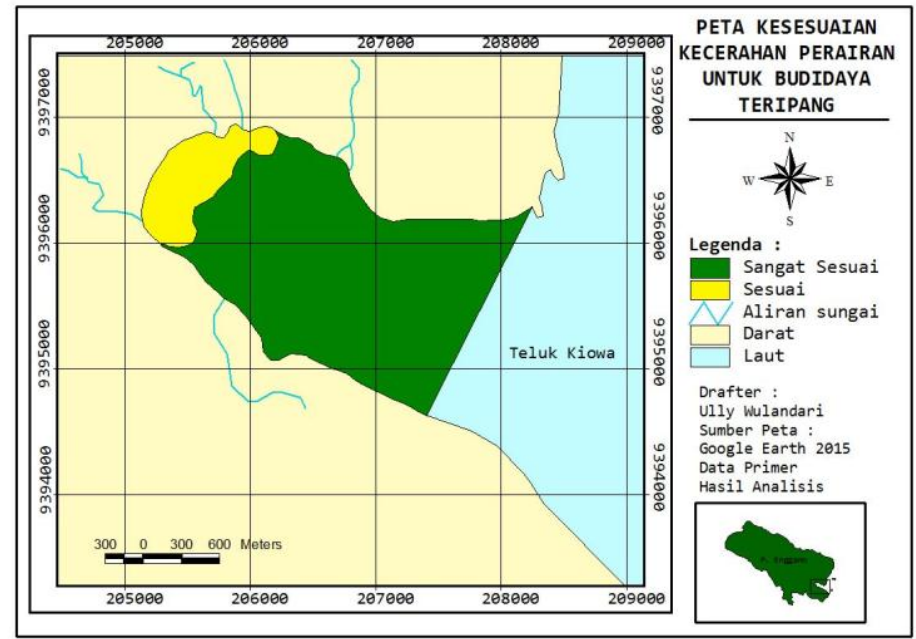

Gambar 7. Peta Kecerahan

\section{Peta Salinitas}

Kelas salinitas Sangat Sesuai (S1) garis kontur memiliki rentan nilai 33-34, kelas Sesuai (S2) garis kontur memiliki rentan 24-32 dan kelas Tidak Sesuai (S3) memiliki rentan nilai 15-23. Langkah berikutnya adalah melakukan analisis spasial, sehingga akan dapat dibandingkan hasilnya dengan gambaran yang sudah ada berdasar peta kontur salinitas (Gambar 8), sehingga luas kesesuaian salinitas perairan dapat diketahui nilainya seperti yang telah disajikan pada Tabel 7.

Tabel 7. Tabel luas kelas kesesuaian salinitas perairan

\begin{tabular}{llll}
\hline No & Kelas Kesesuaian & Luas $(\mathrm{Ha})$ & Luas (\%) \\
\hline 1 & Tidak Sesuai & 66,890 & 18,28 \\
\hline 2 & Sesuai & 69,502 & 18,99 \\
\hline 3 & Sangat Sesuai & 229,512 & 62,73 \\
\hline Total & & 365,903 & 100 \\
\hline
\end{tabular}

Berdasarkan data hasil penelitian, bagian perairan dengan salinitas yang Sangat Sesuai (S1) untuk Budidaya Teripang Pasir (Holothuria scabra) adalah seluas $229,512 \mathrm{Ha}$. Salinitas yang Sesuai (S2) adalah perairan dengan salinitas $24 \%$ - $32 \%$ seluas 69,502 Ha, pada bagian perairan ini salinitas dikatakan sesuai karena salinitas yang dimiliki tidak optimal, dikarenakan pada bagian perarian ini terdapat dua aliran sungai dengan ukuran kecil sehingga keberadaannya mempengaruhi salinitas. Kategori salinitas yang Tidak Sesuai (S3) adalah perairan dengan salinitas dibawah $24 \%$ karena terdapat 3 aliran sungai yang cukup besar sehingga mempengahuri salinitas pada perairan Teluk Kiowa. Hasil dari proses analisis ini dapat dilihat pada Gambar 9. 


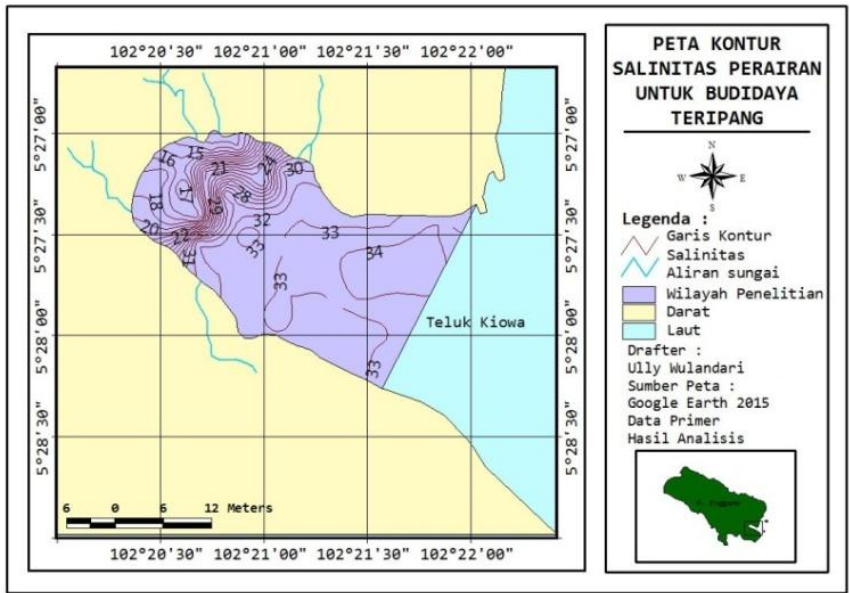

Gambar 8. Peta Kontur Salinitas

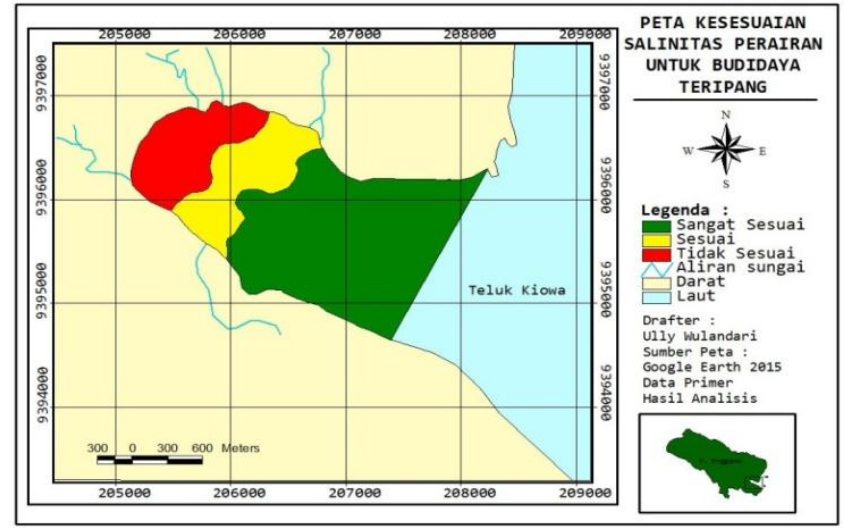

Gambar 9. Peta Salinitas

\section{Peta Derajat Keasaman}

Menurut Wibowo et al., dalam Agusta (2012) nilai Derajat Keasaman $(\mathrm{pH})$ yang baik adalah $6,5-8,5$, sedangkan pada lokasi penelitian $\mathrm{pH}$ berkisar 7,7 8,3. Garis kontur yang terbentuk terlihat pada Gambar 10, luas kesesuaian derajat keasaman perairan disajikan pada Tabel 8.

Tabel 8. Tabel luas kelas kesesuaian derajat keasaman perairan

\begin{tabular}{llll}
\hline No & Kelas Kesesuaian & Luas $(\mathrm{Ha})$ & Luas $(\%)$ \\
\hline 1 & Tidak Sesuai & 0 & 0 \\
\hline 2 & Sesuai & 0 & 0 \\
\hline 3 & Sangat Sesuai & 365,903 & 100 \\
\hline Total & & 365,903 & 100 \\
\hline
\end{tabular}

Hasil interpolasi dan analisis spasial yang telah dilakukan menyatakan bahwa Perairan Teluk Kiowa berada pada status Sangat Sesuai (S1) untuk dilakukan Budidaya Teripang Pasir (Holothuria scabra). Hasil dari proses analisis ini dapat dilihat pada Gambar 11. 


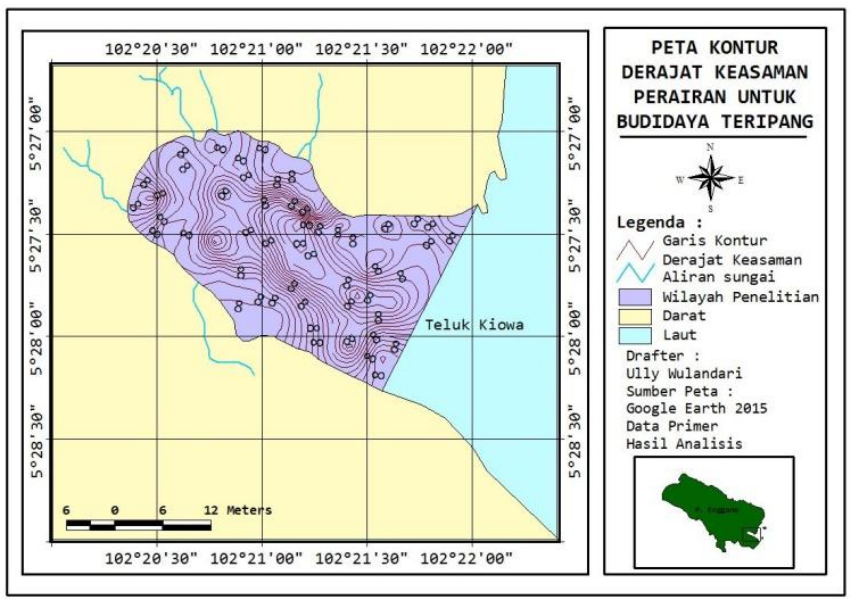

Gambar 10. Peta Kontur Derajat Keasaman

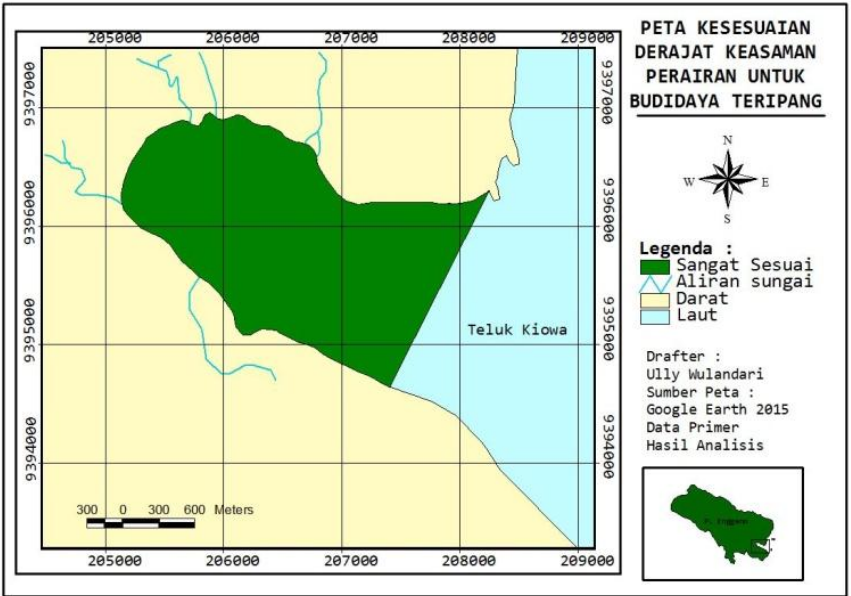

Gambar 11. Peta Derajat Keasaman

\section{Peta Keterlindungan}

Keterlindungan untuk lahan budidaya teripang dibutuhkan untuk menjaga kelangsungan hidup dari teripang yang akan dibudidaya. Peta kontur keterlindungan ini ditampilkan pada Gambar 12, menunjukkan bahwa seluruh kawasan perairan teluk merupakan perairan yang terlindung. Hasil analisis ditampilkan dalam bentuk peta keterlindungan seperti yang terlihat pada Gambar 13 dan dapat diketahui luasannya berdasar Tabel 9.

Tabel 9. Tabel luas kelas kesesuaian keterlindungan perairan

\begin{tabular}{llll}
\hline No & Kelas Kesesuaian & Luas $(\mathrm{Ha})$ & Luas (\%) \\
\hline 1 & Tidak Sesuai & 0 & 0 \\
\hline 2 & Sesuai & 0 & 0 \\
\hline 3 & Sangat Sesuai & 365,903 & 100 \\
\hline Total & & 365,903 & 100
\end{tabular}




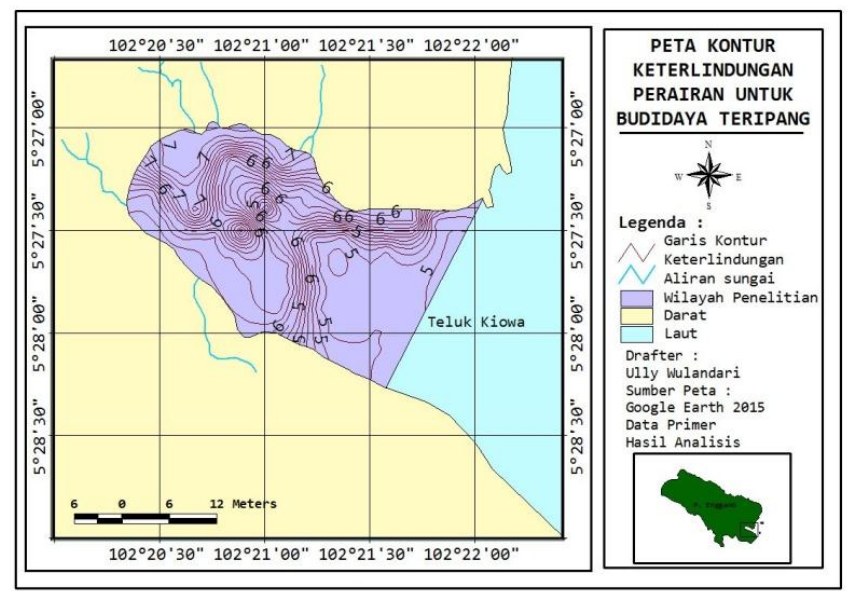

Gambar 12. Peta Kontur Keterlindungan

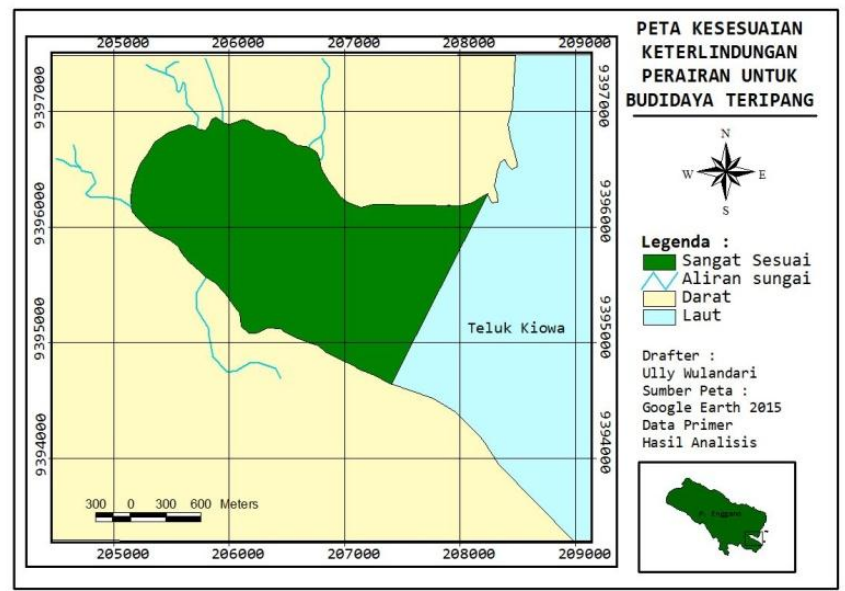

Gambar 13. Peta Keterlindungan

Hasil analisis diperkuat dengan pernyataan Efendi (2004) dalam Sallata (2006) bahwa perairan teluk relatif terlindungi dari ombak besar, badai, dan angin. Sirkulasi air yang masuk banyak dipengaruhi oleh arus akibat pasang surut air laut. Arus laut relatif lambat pada perairan dengan kisaran pasang surut yang kecil $(0,01-0,10 \mathrm{~m} /$ detik) sehingga sirkulasi air di perairan akan relatif kecil. Arus didalam penelitian ini tidaklah digunakan sebagai parameter utama pembobotan dan skoring dalam penentuan lahan budidaya, tetapi arus digunakan sebagai acuan dalam menentukan keterlindungan Perairan Teluk Kiowa, sehingga data yang diambil benar-benar akan valid. Dari hasil pengambilan data pada setiap titik sampling, arus terendah Perairan Teluk Kiowa adalah $0,06 \mathrm{~m} / \mathrm{sec}$ dan arus tertinggi adalah $0,10 \mathrm{~m} / \mathrm{sec}$.

\section{Peta Suhu Permukaan Laut}

Menurut Junianto $d k k$., (2013) suhu optimum untuk larva teripang adalah $28^{\circ} \mathrm{C}-2^{\circ} \mathrm{C}$ sedangkan teripang dewasa suhu yang dapat di tolerir adalah $28^{\circ} \mathrm{C}$ $31^{\circ} \mathrm{C}$. Dalam Gambar 14 garis kontur menunjukkan bahwa secara keseluruhan Perairan Teluk Kiowa memiliki kisaran suhu yang Sangat Sesuai (S1) untuk dilakukan budidaya Teripang Pasir (Holothuria scabra). Luas kesesuaian suhu permukaan perairan dapat diketahui dan disajikan pada Tabel 10. 


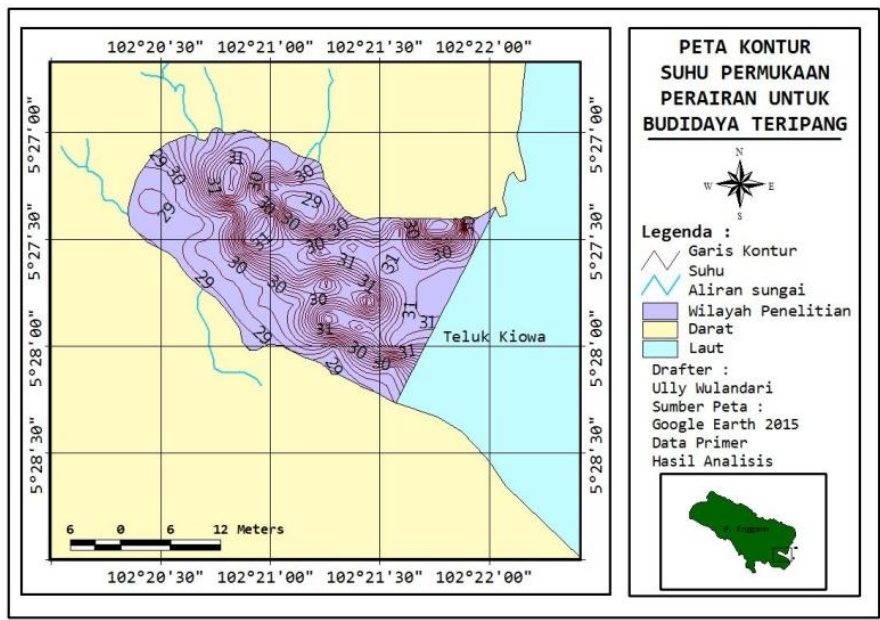

Gambar 14. Peta Kontur Suhu Permukaan Laut

Tabel 10. Tabel luas kelas kesesuaian suhu permukaan perairan

\begin{tabular}{llll}
\hline No & Kelas Kesesuaian & Luas $(\mathrm{Ha})$ & Luas $(\%)$ \\
\hline 1 & Tidak Sesuai & 0 & 0 \\
\hline 2 & Sesuai & 0 & 0 \\
\hline 3 & Sangat Sesuai & 365,903 & 100 \\
\hline Total & & 365,903 & 100
\end{tabular}

Disimpulkan bahwa suhu seluruh bagian dari lokasi penelitian ini, yaitu Perairan Teluk Kiowa berada pada status Sangat Sesuai seperti yang terlihat pada Gambar 15.

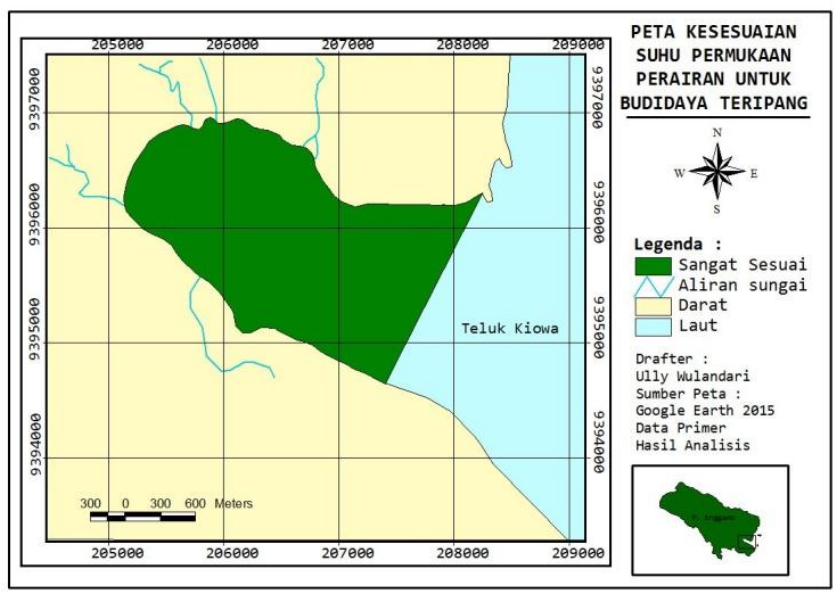

Gambar 15. Peta Suhu Permukaan Laut

\section{Peta Kandungan Oksigen Terlarut}

Oksigen didalam budidaya laut selalu menjadi parameter yang diperhitungkan sebagai kriteria kesesuaian. Peta kontur kandungan oksigen terlarut yang ditampilkan pada Gambar 16 memiliki range garis 6-8 dan luas kesesuaian kandungan oksigen terlarut perairan disajikan pada Tabel 11. 


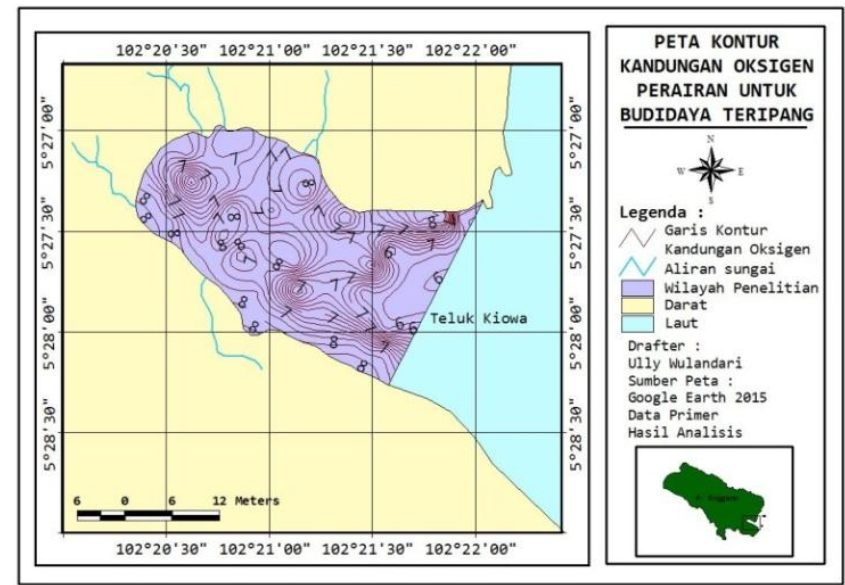

Gambar 16. Peta Kontur Kandungan Oksigen Terlarut

Tabel 11. Tabel luas kelas kesesuaian Kandungan Oksigen Terlarut

\begin{tabular}{|c|c|c|c|}
\hline No & Kelas Kesesuaian & Luas $(\mathrm{Ha})$ & Luas (\%) \\
\hline 1 & Tidak Sesuai & 0 & 0 \\
\hline 2 & Sesuai & 0 & 0 \\
\hline 3 & Sangat Sesuai & 365,903 & 0 \\
\hline Total & & 365,903 & 100 \\
\hline
\end{tabular}

Kandungan oksigen terlarut pada Perairan Teluk Kiowa berkisar antara 6,15$7,81 \mathrm{ppm}$. Sebelumnya dalam penelitian yang dilakukan oleh Ta'alidin dkk (2014), kandungan oksigen pada beberapa perairan di Pulau Enggano termasuk dalam kategori sangat bagus. Dengan demikian dapat dikatakan pula bahwa kandungan oksigen pada Perairan Teluk Kiowa berada dalam kelas Sangat Sesuai (dapat dilihat pada Gambar 17), sama seperti yang dikemukakan dalam penelitian sebelumnya disekitar Pulau Enggano.

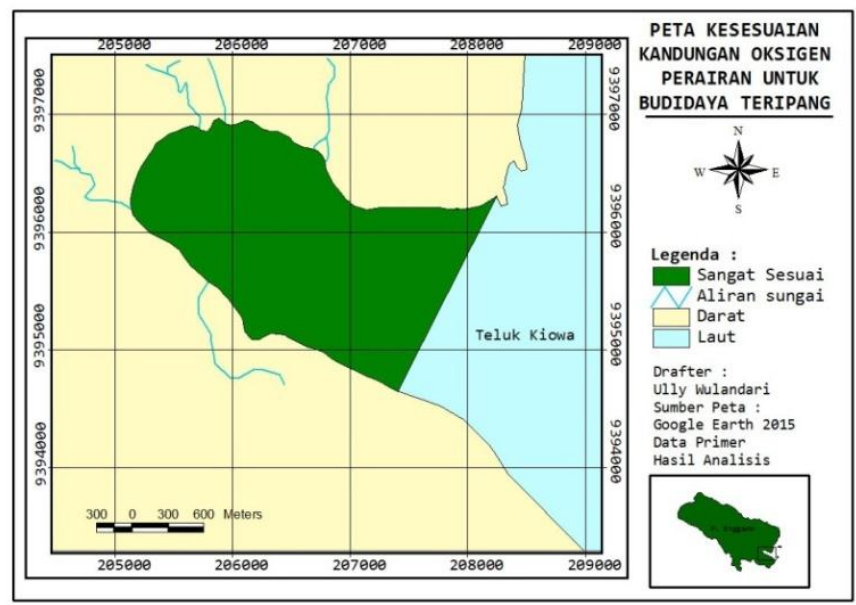

Gambar 17. Peta Kandungan Oksigen Terlarut

\section{Hasil Analisis Kesesuaian Kawasan Budidaya}

Peta Kesesuaian Kawasan Budidaya pada penelitian ini merupakan peta hasil analisis overlay dari ke-delapan parameter yang diukur. Data atribut dari setiap parameter kemudian dijumlah dan dibagi dengan jumlah nilai keseluruhan 
bobot yang digunakan sehingga akan menghasilkan Total Nilai yang membuat kawasan terbagi atas tiga kelas, yaitu Sangat Sesuai (S1), Sesuai (S2), dan Tidak Sesuai (S3). Luas kesesuaian Kawasan Budidaya Teripang Pasir (Holothuria scabra) disajikan pada Tabel 12. Hasil analisis spasial dapat dilihat pada Gambar 18.

Tabel 12. Tabel luas kelas kesesuaian kawasan budidaya

\begin{tabular}{llll}
\hline No & Kelas Kesesuaian & Luas $(\mathrm{Ha})$ & Luas $(\%)$ \\
\hline 1 & Tidak Sesuai & 197,991 & 54,11 \\
\hline 2 & Sesuai & 62,435 & 17,06 \\
\hline 3 & Sangat Sesuai & 102,477 & 28,83 \\
\hline Total & & 365,903 & 100 \\
\hline
\end{tabular}

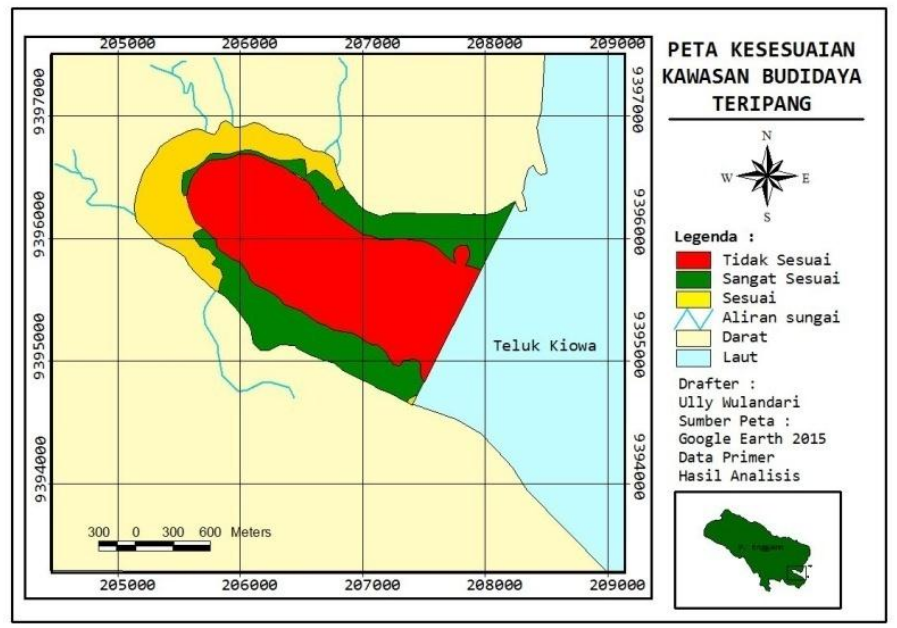

Gambar 18. Peta Kesesuaian Kawasan Budidaya Teripang Pasir (Holothuria scabra)

\section{KESIMPULAN DAN SARAN}

\section{Kesimpulan}

Berdasarkan hasil analisis, Perairan Teluk Kiowa memiliki kawasan yang Sangat Sesuai (S1) untuk dijadikan sebagai Kawasan Budidaya Teripang Pasir (Holothuria scabra) seluas $102,477 \mathrm{Ha}$, dengan persentase $28,83 \%$. Kawasan Sesuai (S2) seluas $62,435 \mathrm{Ha}$, dengan persentase 17,06\%, dan kawasan Tidak Sesuai (S3) seluas 197,991 Ha, dengan persentase terbesar, yaitu $54,11 \%$. Kawasan ini merupakan kawasan dengan kedalaman yang lebih dari 1,5 meter sehingga untuk kawasan budidaya dengan metode penculture ini sangatlah tidak sesuai.

\section{Saran}

Setelah dilakukan penelitian ini, saran yang dapat diberikan adalah: perlu dilakukan penelitian lanjutan dengan titik sampling yang lebih banyak, sehingga hasil interpolasi akan lebih smooth dengan ketelitian lebih baik, parameter dalam pengambilan data diharapkan lebih banyak sehingga penilaian akan lebih komplit, penelitian dilakukan untuk fungsi kawasan budidaya yang lain.

\section{DAFTAR PUSTAKA}


Agusta, O. R., Suliardono, Bambang dan Siti Rudiyanti. 2012. Kebiasaan Makan Teripang (Echinodermata : Holothuriidae) di Perairan Pantai Pulau Pramuka, Kepulauan Seribu. Journal Of Management Aquatic Recources. Vol.1. No.1. Hal 1-8

Badan Penelitian dan Pengembangan Pengelolaan Sumberdaya Perairan dan Lingkungan Universitas Riau. 2009. Laporan Akhir Studi Potensi Dan Pengembangan Budidaya Laut Di Lokasi Coremap II Kabupaten Lingga

Dinas Kelautan dan Perikanan Propinsi Bengkulu dan CV. Mitra Konsultan. 2004. Laporan Akhir Penyusunan Tata Ruang Dan Potensi Pulau Enggano. Hal.1-3

Firdausi, Mawar. $2010 . \quad$ Budidaya $\quad$ Teripang. http://mawarfirdausi.blogspot.com/2010/05/teripangkeindaha.html.

Diakses Tanggal 10 Februari 2015

Hertanto. Hendrik, $2012 . \quad$ Goby. Kontur. http://geoenviron.blogspot.com/2012/04/garis-kontur.html. Diakses Tanggal 14 Februari 2015

Junianto, Dwi. 2013. Studi Ekologi Teripang (Holothuroidea) di Perairan Desa Pengudang Kabupaten Bintan.Jurnal Penelitian Fakultas IImu Kelautan dan Perikanan. Universitas Maritim Raja Ali Haji: Riau

Kementrian Kelautan dan Perikanan. 2012. Budidaya Teripang (Holothuria scabra). Jurnal Kelautan dan Perikanan

Marizal, Dendi., Yales V. J. dan Henky Irawan. 2012. Aplikasi SIG Untuk Kesesuaian Kawasan Budidaya Teripang Holothuria scabra dengan Metode Penculture di Pulau Mantang, Kabupaten Bintan. Jurnal Penelitian Fakultas IImu Kelautan dan Perikanan. Universitas Maritim Raja Ali Haji: Riau

Munirwansyah., Sundary. Devi., dan Gartika Setiya Nugraha. Inerpretasi Bearing Layer (Kontur Lapisan Tanah Keras) Dibawah Permukaan dengan Program Surfer. Jurusan Teknik Sipil, Fakultas Teknik Universitas Syiah Kuala. Banda Aceh

Sallata.Alfiani. E. 2006. Kajian Potensi Sumberdaya Untuk Pengelolaan Budidaya Rumput Laut dan Ikan Kerapu di Wilayah Pesisir Kecamatan Ampibabo, Kabupaten Parigi Moutong, Sulawesi Tengah.Fakultas Perikanan dan Ilmu Kelautan. Institut Pertanian Bogor

Ta'alidin. Z., Bachtiar. D., Wilopo. M. D. 2014. Kondisi Terumbu Karang Di Pulau Enggano. Laporan Penelitian. Balai Penelitian Universitas Bengkulu. Hal. 60. 